\title{
Evaluation of composite structures by light microscopy and image analysis
}

Lenka Markovicova ${ }^{1}$, Lenka Hurtalova ${ }^{1}$, Viera Zatkalikova ${ }^{1}$, Tomasz Garbacz ${ }^{2}$

${ }^{1}$ Faculty of engineering, Department of materials engineering, University of Zilina, Univerzitna 8215/1, 01026 Zilina, Slovakia, E-mail: lenka.markovicova@fstroj.uniza.sk

${ }^{2}$ Mechanical Engineering Faculty, Department of Polymer Processing, Lublin University of Technology, 36 Nadbystrzycka St., 20-640 Lublin, Poland, E-mail: t.garbacz@pollub.pl

A composite is a material which is made up of two or more distinct materials. Composite materials are generally used for buildings, bridges and structures such as boat hulls, swimming pool panels, race car bodies, shower stalls, bathtubs, storage tanks, imitation granite and cultured marble sinks and counter tops. As a result of absorption of liquids usually occurs a change in volume, which is referred to as swelling. This process can give rise to physical and chemical properties of polymers.NIS - Elements 3.0 was used to evaluate the microstructure of composite materials with different contents of ferrite powder filler. Using NIS - Elements 3.0 assessed the number of particles $\mathrm{Sr}$ ferrite surface area and perimeter $\mathrm{Sr}$ ferrite particles and the volume fraction of $\mathrm{Sr}$ ferrite in the microstructure.

Keywords: composite, polyethylene, image analysis, chemical resistance, powder filler

\section{Acknowledgement}

The research is supported by European Regional Development Fund and Slovak state budget by the project „Research Centre of the University of Žilina“, ITMS 26220220183 and project ITMS 26110230117.

\section{References}

[1] HAVALDA, A. (1994): Kompozitné matetriály. STU Bratislava

[2] VALÁŠEK, P., MÜLLER, M. (2012): Polymeric particle composites with filler saturated matrix. Manufacturing and technology, Vol. 12, No. 13, p. 272-276

[3] NOVAKOVA-MARCINCINOVA, L., NOVAK-MARCINCIN, J. (2014): Production of ABS-Aramid composite material by fused deposition modelig rapid protopyping. Manufacturing technology, Vol.14, No. 1, p. 85-91

[4] GUTFLEISH, O. (2001): Hard Magnetic Materials, Basic Principles Encyclopedia of Material: Science and Technology, Elsiever Science Ltd, ISBN: 0-08-0431526, s. 3719-3722

[5] LOKANDER, M., REITBERGER, T., STENBERG, B. (2004): Polymer Degradation and Stability, 86, s. $467-471$

[6] MARKOVIČOVÁ, L. (2009): Kompozitné materiály s magnetickými plnivami. Dizertačná práca, STU Bratislava

[7] TOR-ŚWIĄTEK, A. (2013): Evaluation of the effectiveness of the microcellular extrusion process of low density polyethylene. Eksploatacja i Niezawodnosc - Maintenance and Reliability, Vol. 15, No. 3, p. 225-229. 